\title{
Cross-examination: An interrogation of Peter Rollins's hermeneutic of the crucifixion
}

\author{
Duncan Reyburn \\ University of Pretoria, South Africa
}

\begin{abstract}
This article, which is argumentative in nature, interrogates and critiques Peter Rollins's hermeneutic of the crucifixion. This is done by calling into question Rollins's reliance upon the writings of Slovenian dialectical materialist Slavoj Žižek, especially with regard to the focus on the cry of dereliction. It is argued, ultimately, that Rollins's hermeneutic of the crucifixion contravenes the very co-ordinates that he has set up for his own theological-political project and argues for critically rethinking the way that otherness is conceived of in the hermeneutics of the emergent church milieu that Rollins is proposing.
\end{abstract}

\section{Keywords}

G. K. Chesterton, Crucifixion, Cry of dereliction, Doubt, Emerging Church, Faith, Hermeneutics, Peter Rollins, Slavoj Žižek

\begin{abstract}
"Is it possible then that Jesus himself not only wanted Judas to betray him but actually demanded it? ... It is with such a reading in mind that the philosopher and cultural theorist Slavoj Žižek goes so far as write that, while 'in all other religions, God demands that His followers remain faithful to Him - only Christ asked his followers to betray Him in order to fulfil His mission" - Peter Rollins (2008:21).
\end{abstract}

Peter Rollins has become an important and influential figure in the 'emerging' or 'emergent church milieu' that has become a new voice for ecclesiology especially in the UK and America (McKnight 2007; Moody 2010:498; 2012:187). Much of Rollins's project is geared towards developing a kind of dialogical community where the identities of participants are acknowledged beyond merely affirming labels. This is to say that he is attempting to contribute to a kind of post-tribal, politically rather than doctrinally motivated Christianity — an a/theistic Christianity that constantly calls its own dogmas into question. It is clear that Rollins's project has some obviously positive aims, especially with regard to developing an inclusionary and participatory conversation geared toward promoting a new egalitarian community of love and respect. However, I notice that Rollins's hermeneutic practice seems to produce several theological-political constructions that, in my view at least, violate his very

\footnotetext{
Corresponding author:

Duncan Reyburn

Email: duncan.reyburn@up.ac.za
} 
aims, and it is the goal of this article to explore precisely what I mean when I say this.

Rollins (2008:118) notes the importance of Kierkegaard's notion of "radical subjectivity" in his own thinking. Truth, for him, is something that "transforms a person's subjectivity" rather than something that is found in propositions about objective realities (Rollins 2008:118). This idea, which does not quite account for Kierkegaard's retention of the importance of the objective, is found in various transmutations throughout his writings. For him, the experience of 'faith beyond belief' is primarily an issue of transforming how we see and understand. It involves becoming aware of the ground from which meaning is derived rather than simply changing what we see and understand. This is to say that Rollins's project is fundamentally interpretive: it has everything to do with encouraging the transformation of perceptions. It appears that this shift towards this radical subjectivity comes in the face of Rollins's (2006:2) observation that the 'contemporary Church ... is always in danger of intellectual idolatry' that gives rise to various fundamentalisms and conflicts. In other words, the objects and objectives - rituals and liturgies - of belief can easily overwhelm the subjectivity of love that is at the heart of ecclesial mission (Rollins 2006:3).

Thus, Rollins certainly seems to have attempted to create a humbler, more playful discourse around Christian theology and praxis in a postmodern context, bearing in mind some of the intra- and intercommunal tensions that arise in the aftermath of dogmatic theology. Nevertheless, it is my contention that if there is one failing in Rollins's project, it is his over-reliance upon and uncritical adoption of the writings, and especially the hermeneutical

\footnotetext{
${ }^{1}$ In addition to leaning on the work of Žižek, Rollins (2012:196) acknowledges other thinkers whose work has been significant for him, including Frederiek Depoortere, Bruce Fink, Paul Hessert and Jacques Lacan, and the voices of Meister Eckhart, Søren Kierkegaard and Dietrich Bonhoeffer can also be heard through his writings and public lectures. This list of influences is certainly not exhaustive. Moody (2011:188) points out that Rollins is also a follower of John D. Caputo, Jacques Derrida, Martin Heidegger, Emmanuel Levinas, Jean-Luc Marion and even Friedrich Nietzsche. However, it is my contention that while Rollins has been influenced by many, he is most clearly a disciple of Žižek.
}

approach, of the Slovenian dialectical materialist Slavoj Žižek. ${ }^{1}$ As I attempt to make more evident below, Žižek's work, even as it is adapted by Rollins, violates the co-ordinates that Rollins himself has set up. For one thing, Rollins $(2006: 3,66)$ seems to desire to keep 'right belief' in tension with 'believing in the right way', but this is certainly not a tension that Žižek's hermeneutics can retain. ${ }^{2}$ My aim here, however, is to focus only on a part of Rollins's theology, rather than on the whole. Even at the risk of being overly polemical, I want to zoom in on the aspect of Rollins's theology that seems to most expose Žižek's hold on his interpretive practice, namely the cry of dereliction from the crucified Christ that acts as the catalyst for a postmetaphysical theology (Pound 2008:23; Rollins 2011a:21; Žižek 1992:190; 2003:171; Mark 15.34; Matthew 27.6). ${ }^{3}$ With this focus in mind, I want to stress that the following interrogation is in no way meant to undermine the value of what Rollins is bringing into discourse around creating a new kind of church. My particular emphasis here is not meant to be taken as a universal critique of his entire body of work; it is merely an interrogation of one aspect of his hermeneutics.

\footnotetext{
${ }^{2}$ It should be mentioned, however, that Rollins is somewhat ambivalent towards orthodoxy at certain points. He argues, for instance, that "[o]rthodoxy as right belief will cost us little; indeed, it allows us to sit back with our Pharisaic doctrines, guarding the 'truth' with the purity of our interpretations. But orthodoxy, as believing in the right way, as bringing love to the world around us and within us ... that will cost us everything" (Rollins 2006:3). This is a fairly subtle rhetorical move in that it allows him to set himself up as somehow beyond reproach. Anyone who attacks his thinking may quickly be branded a 'Pharisee', since the focus of any such attack would have to be at the level of 'right belief'. My aim here, however, is to demonstrate in part that without some form of right belief, orthopraxy is itself in jeopardy.
}

3 This is a deeply political emphasis, since in claiming to move away from the dematerialised rationality of secular reason, it tries to set up a counter-movement or insurrection that proposes a thoroughly materialistic view of the human subject. For Žižek, this compliments his Lacanian-Marxist sensibilities, and for Rollins this allows an emphasis on a community of love. Nevertheless, the fact that Rollins's theology mirrors the politics of Žižek may make it difficult to tell the difference between Žižek's communist party and his own vision of the church. 
That Rollins, like Žižek, emphasises the cross of Christ may initially be viewed as typically Pauline, although this is not to say that it sticks strictly to the Pauline formulation of this emphasis (1 Corinthians 1.23; Galatians 6.14). On the crucifixion, Rollins (2006:77-78) writes that ' $[\mathrm{t}] \mathrm{o}$ imagine that the horror of the cross is exhausted in the physical pain or profound injustice that it symbolizes is to misunderstand the true horror of this symbol. While the image of suffering is truly harrowing, it is not the only or even the central horror of this central event'. The 'central horror', for him, is allocated to the trauma that gives rise to Christ's 'seeming ... abandonment by God' (Rollins 2006:78). In this emphasis, he situates himself within a psychological rather than theological reading of the cry of dereliction. Thus, he presupposes the importance of 'psychologically inhabiting that rarely mentioned [Holy] Saturday between Good Friday and Easter Sunday' (Rollins 2006:78, 81). One may be tempted to read this as Rollins's attempt to promote a more paradoxical theological between-space, whereby one simultaneously acknowledges the trauma of a past event, as well as the future hope of a resurrection event. However, this is not exactly how Rollins articulates his meaning. Rather, he encourages adopting the position of the disciples of Christ who were unable to look forward to the resurrection with any sort of certain hope. As far as they were concerned, they dwelt within the intense grief of that Holy Saturday, having had their entire point of identification, religious calling and socio-political purpose destroyed. In this, Rollins posits the absence of God as an essential component of the religious experience that should be present in both trauma and healing; the sense of the absence of God ought not to be entirely erased even when resurrection Sunday has happened (Rollins 2006:81).

Rollins uses a story to illustrate what he means. He tells of a fictional community that had never come to hear of the resurrection of the Christ, but had nonetheless chosen to follow his teachings (Rollins 2006:80): 'Here we are presented with a community who followed Christ not because of a resurrection but because of a seduction. They knew what that cry of abandonment really meant, for they had lived with it for as long as they could remember' (Rollins 2006:81). To these people, the news of the resurrection comes almost with a sense of disappointment. For them, the expectation for God's arrival must still reinforce his inevitable absence - an absence that brings us to long for God even in his presence (Rollins 2009:81). Instead of articulating life as being bound to the tension between longing in belonging, Rollins performs his thinking around an apparently unquenchable longing. For him, the dark night of the soul should not give into the temptation of keeping the nightlight on. He therefore positions the human subject firmly within a void: '[W]e enter the world with one thing in our possession: nothingness itself' (Rollins 2012:14).

In the above story about the pre-resurrection community, Rollins appears at first to be introducing doubt as a condition of authentic faith. However, while doubt is certainly a virtue in his wider body of work, what is being proposed here is not doubt but rather a mode of almost extreme epistemological certitude. His emphasis indicates that we can only be certain of the historicity of Christ crucified; we cannot be at all certain of his resurrection. This plays into Rollins's fondness for a common post-structural absolute: We cannot be assured of such an arrival, but only of departure (Rollins 2006:6). ${ }^{4}$ Therefore, it seems that we ought to turn only to what we can be sure of, namely our personal ethics in the face of the trauma of the cross. In the face of mystery - something that Rollins emphasises even to the point of excess - and

\footnotetext{
${ }^{4}$ It is in accordance with this same reasoning that Rollins writes that 'Resurrection neither negates the Crucifixion nor moves beyond it' (Rollins 2011a:161). I recognise, of course, that he is trying to set up a certain measure of rhetorical force in this statement, but what is perplexing is precisely the fact that it is arguable that a Resurrection that does not move beyond Crucifixion is not a Resurrection at all. In Rollins's view, the trauma of the cross must be reiterated to the point of aporia. This, I think, contravenes his desire for a faith beyond belief, since it holds quite dogmatically to a very particular belief.
} 
perhaps at the risk of resorting to linguistic idealism, praxis becomes the new absolute: 'our practices do not fall short of our beliefs, but are the concrete, material expression for them. In other words, our outer world is not something that needs to be brought into line with our inner world but is an expression of it' (Rollins 2011a:103). This sets up Rollins's insistence that our true self is best understood in terms of our total being - our full engagement with others and the world. In his view, the disjunction between thought and action is in particular need of attention. This is arguably very closely related to the emphasis placed by Jesus during his ministry on the problems of hypocrisy. The Jewish conception of shalom also comes to mind in its representation of God's desire for the wholeness of his created order.

Rollins still regards the cry of dereliction as a 'seeming ... abandonment by God' in his first book (Rollins 2006:78, emphasis added). This reading is taken from the post-Victorian writer G. K. Chesterton (2002:201), who contends that there is 'only one divinity who ever uttered [the isolation of the atheists]; only one religion in which God seemed for an instant to be an atheist' (emphasis added). However, by the time his fourth book Insurrection is released, Rollins has absolutised his psychological reading of the cry of dereliction. No longer does God just seem to be an atheist, but in fact becomes an atheist: 'On the cross we are confronted with God losing the security of God' (Rollins 2011a:20-21). Rollins's emphasis strongly echoes Žižek's (2003:15) reading of Chesterton: 'In the standard form of atheism, God dies for men who stop believing in Him; in Christianity, God dies for Himself'. Rollins claims that the 'true scandal of the Cross' is not found in the fact that an innocent man is executed, nor in the assertion that love will be violently opposed by those who are filled with hatred, but is found instead in the fact that 'God loses everything' (Rollins 2011a:21). 'On the cross, Christ undergoes the deepest, most radical form of divine loss, one that is experienced' (Rollins 2011a:21).
Whereas the Pauline emphasis on the cross is clearly paradoxical in that this defeat in fact turns out to be an expression of victory (a true deconstruction of the power structures of worldly systems), Rollins forgets the paradox. The Cross becomes only loss.

Rollins is adamant that he thinks that the cry of dereliction is not, as is often claimed, just a quotation of Psalm 22, which when taken as a whole 'expresses deep belief' (Rollins 2011a:25). He explains that 'the cry recorded in the Gospels of Matthew and Mark is put in Jesus' native tongue (Aramaic) rather than in the psalm's original Hebrew' thus indicating for him that the cry was a deeply 'heartfelt cry of agony' and not just a carefully planted remez. Rollins's reasoning here, by relying too heavily on psychologism, is not very robust. He ultimately does not make it clear why we ought to reject the traditional reading. If Jesus wanted to quote scripture in his native tongue rather than in Hebrew, there is no reason why the reader should oppose him. That he may have been quoting Psalm 22 and thus expressing deep belief must surely remain a hermeneutic possibility, even for the deconstructionist. Perhaps, as I explore in more detail further on, Rollins wants to insist upon setting Jesus up as a doubting Thomas simply as a way of confirming his own interpretive assumptions. In doing so, he must call the integrity and consistency of the original text into question. Moreover, by extension and as I argue in more detail further on, he must call his own theological project into question.

It is worth noticing, however, that Chesterton (1993:212), whose reading of the cry of dereliction acts as inspiration to Rollins (after Žižek 2003:15), resists over-interpreting this cry even while he acknowledges that it seems to make an atheist out of Jesus. Instead, he writes that 'there were solitudes beyond where none shall follow,' indicating that insofar as the reader should be concerned, the agony of Christ is not decipherable in any absolute terms, nor is it something that any other human being will necessarily ever experience: 
There were secrets in the inmost and invisible part of that drama that have no symbol in speech; or in any severance of man from men. Nor is it easy for any words less stark and single-minded than those of the naked narrative even to hint at the horror of exaltation that lifted itself above the hill. Endless expositions have not come to the end of it, or even to the beginning. And if there be any sound that can produce silence, we may surely be silent about the end and the extremity; when a cry was driven out of that darkness in words dreadfully distinct and dreadfully unintelligible, which man shall never understand in all eternity they have purchased for him; and for one annihilating instant an abyss that is not for our thoughts had opened even in the unity of the absolute; and God had been forsaken of God (Chesterton 1993:212).

Chesterton claims here that it is impossible to conceive of this momentary rupture in the unity of the absolute, if indeed that is what it is. If God had truly been forsaken of God, Chesterton offers that no one can traverse the extent of that abyss, or even map out its meaning. The mystery here is that the Incarnate God alone subjectively knows what this experience is, and his cry does not even begin to provide an explanation of his own turmoil. Nevertheless, it is the very mystery that Chesterton regards as falling completely beyond any human utterance that Rollins seems to claim to understand. Where Chesterton admits ignorance, thus leaving open the possibility that this is still not an ontological separation, Rollins founds a theological system. Rollins (2011a:22) writes:

On the Cross, Christ is rejected by his friends, betrayed by the religious authorities, and crucified by the political leaders. We witness here, in the starkest terms, the loss of all those structures that ground us and give us the comfort that life makes sense. More than this, Christ experiences the loss of that which grounds each of these realms - God.

The first part of the above passage is hardly disputable: the narrative of the Gospels indicates that Christ indeed experiences a 'loss of all those structures that ground us' (Rollins 2011a:22). However, Rollins then makes a bold move, claiming that God is the very ground of those worldly structures of meaning: friendship, religious authority, politics, and so on. Moreover, he claims that it is precisely this God that Christ loses (Rollins 2011a:38-39, 51). It is, in other words, this God that dies. It does not take much effort to problematise this reading. Here, Rollins, like Žižek, equates God - the God that Christ experiences the loss of - with Lacan's notion of the big Other (the social-symbolic system that mediates our relationships): 'In Lacanian terms, we are dealing with the suspension of the big Other, which guarantees the subject's access to reality: in the experience of the death of God, we stumble upon the fact that the big Other doesn't exist [l'Autre n'existe pas]" (Žižek 2005:42). This God, as the big Other who is lost, is merely the ground of the symbolic order. In order to uphold this reading, Rollins has to assume that Jesus' so-called 'existential atheism' implies a rupture between himself and a kind of 'false God' - a 'deus ex machina ... God of philosophy' (Rollins 2011a:12, 14; 2012:127).

Furthermore, to remain consistent with this view, Rollins would have to assume two things: firstly, that Jesus and the God he had spoken of in his teachings were not co-eternal in their oneness within the Trinity, and, secondly, that Jesus had somehow been wrong about the kind of God that he was talking about and in communion with throughout his ministry. In other words, Rollins would have to assume that Jesus' entire theological project had been somehow unequivocally supportive of the social, religious and political structures of his day, when it is clearly more easily read as a critique of these very structures. ${ }^{5} \mathrm{He}$ would have to assume, therefore, that Jesus had been somehow disconnected from the true God all along, but had not

\footnotetext{
${ }^{5}$ Rollins (2011a:156) is correct, therefore, to suggest that Christianity is fundamentally geared towards challenging corrupt systems. This is a very important aspect of Rollins's thinking, but, as I argue here, it is not something that his reading of the crucifixion actually supports.
} 
been aware of this until he experienced the trauma of the cross. Thus, on this point, Rollins is perfectly aligned with Žižek: his Christ had perhaps thought himself to be a kind of God, but had come to the realisation that this God (the big Other) does not exist. Rollins's crucified Christ is only a human being when he dies on the cross - a human being caught up in the same ideological-hegemonic trappings as any other human being would be. For him, God (the big Other) as an extension of our desire for security and wholeness, needs to be lost or experienced as dead so that Jesus can fully claim his humanity. However, to narrate the argument in such a way that Jesus fully claims his humanity on the cross, Rollins has to first assume that Jesus was somehow out of line with God, as well as his own humanity. This is the first clear problem with Rollins's reading of the cry of dereliction: it will not allow him to retain his orthodox 'right belief' in the divinity of Christ (Rollins 2012:126). It requires him, therefore, to not only give up God, but to give up Christ as well. Christ becomes, as in Žižek's (2001:51) thinking, a 'vanishing mediator/ medium through whose death God the Father himself "passes into" the Holy Spirit'. In this reading, there is no need for two of the persons of the Trinity; the community of love becomes sufficient to affirm Rollins's materialistic Christianity. To be fair, I recognise that this particular argumentative slant may not have been intended by Rollins himself. Nevertheless, it is the reading that Rollins's own logic leads to.

The above is, in a way, fairly neat until we recall that Rollins also seems to affirm the transcendent God as well as the Divine Christ. If these two tenets of orthodoxy are retained, then we have to assume that Rollins's Žižekian discussion on the crucifixion and the cry of dereliction is purely symbolic of something human beings go through, but which Jesus prefigures in his own cry of dereliction. The trouble here is that Rollins frequently reiterates that the cross should never be merely symbolic or mythological (Rollins 2011a:21). In attempting to avoid turning the crucifixion into a mythology, Rollins has merely arrived with a different mythology. He creates the very 'meaning, order and stability' that he criticises (Rollins 2011a:22).

Having assumed Jesus' traumatic divorce with God as the big Other to be pivotal, Rollins then takes his reading of the cry of dereliction a step further. Not only does it represent the fullest human experience of meaninglessness or the collapse of meaning and the 'breakdown of all worldviews' but it also represents 'the fundamental way of entering into the presence of God' (Rollins 2011a:24; 2012:118). For Rollins, what happens on the Cross is that the God of metaphysics - the deus ex machina, the God of reason and meaning, or the big Other - dies. This allows room for a God who "dwell[s] in our very midst" to be found (Rollins 2011a:160). In this interpretation, God is now no longer a distant representation of our own intellectual processes and selfish, unmet desires, but now becomes a presence felt within our own subjective experiences of loving the other. This complies beautifully with Rollins's pseudo-Kierkegaardian views on subjectivity, but the force of this subjectivity comes at the expense of something, namely our ability to reason. Rollins implicitly places our rational capacities at odds with this transformation of our subjective vision even while he makes use of reason to convince us of the importance of this subjectivity. For Rollins, God cannot be reasoned about at all, thus, for example, ensuring that any form of divisive apologetics gets discarded (Rollins 2006:35).

However, a question arises, namely the question of what the precise nature of this process might be - the process that causes the rational self to recede in the wake of the cyclonic, hypersubjective self. This is not something that Rollins delineates in any detail. Rather, he seems to rely upon the reader to fill in the gaps. Žižek (2005:130) offers that what is required, and what Žižek's Christ experiences, is a passage through madness. Indeed, the Jesus of Rollins and Žižek must be 'mad' in some sense — must develop a kind of split-personality disorder that divorces his supposed divinity (the 
big Other) from his humanity — in order to claim the transformation of his own subjectivity. Indeed, this descent into madness is somewhat logical in that it assumes the disappearance of the ground of meaning, and thus the divorce of the subject from his socio-symbolic world. To the outsider, this break from the 'sanity' of consensus would seem to render the subject mad, because he no longer conforms to the insane hallucinations of his neighbors. Marcus Pound (2008:31) writes that '[f]or Žižek the Christian God is a God who risks madness in creation and self-dereliction on the cross ... Christianity privileges precisely these moments of material 'imperfection': Christianity makes incompleteness higher than completion'.

If Rollins follows Žižek closely here, as his line of argument seems to do, what makes the cry of dereliction so pivotal is precisely this absence of completeness, throwing into question Jesus' perfection, his union with the Father amidst the trauma (Luke 23.46), as well as his cry from the Cross that 'It is finished' (John 19.30). Here, the need for a God to provide meaning, comfort and security is done away with so that reality can be fully experienced for what it is, namely as a distressing disturbance in the texture of existence (Rollins 2011a:48). This trauma of the Real is embedded in the fact that ' God is no longer beyond, but passes into the Holy Spirit (of religious community)' (Žižek 2001:50-51). As a consequence of this separation/death of God, the radical subject must now carry the full weight of responsibility for meaning. In Rollins's (2011a:132) words, 'We Are Destiny'.

The burden of this radical subjectivisation is found in the fact that for Rollins we 'must ... courageously embrace' participation with the cross of Christ; that is, we must experience the loss of God, just as Jesus did (Rollins 2011a:24). Such an emphatic, perhaps even legalistic call, as intimated above, requires us to assume that we can experience exactly what Christ experiences on the Cross. This can only be done, though, if we assume that Jesus was exactly the same kind of human being that we are; that is, we would have to assume, against orthodoxy, that he was in no way a perfect human subject, and also that his authentic divinity did not come into play in his experience on the Cross. This is a fairly uncontroversial position in a great deal of contemporary theological discussion, but it hardly qualifies as something that would encourage anyone to 'transcend the present constellation of conservative, liberal, evangelical, fundamentalist, and orthodox communities' in order to participation in a 'radically new form of Church' (Rollins 2011a:xv). In fact, Rollins seems to be promoting a position that does not transcend anything, but gets stuck in its own dialectical logic. Instead of fostering a reconciliatory politics, Rollins sets up a system of oppositions: Jesus against God, crucifixion against resurrection, trauma against resolution, subjectivity against reason, praxis against theory, mystery against knowledge. The list goes on.

I am not, in all of this, concerned about whether this is Rollins's intention or not, but rather with the way that his hermeneutic of the crucifixion sets up such oppositions. If Rollins is aiming for the goal of a "post-divided and post-divisive theology that is both postconservative and post-liberal, aiming to keep open rather than shut down dialogue, exploration, learning and transformation' as Katherine Moody (2010:499) claims is the larger goal of the emergent church milieu, then surly such oppositions need to be carefully reconsidered? It is for this reason that I think Rollins's hermeneutic approach needs to be cast into question. Rollins would like to set up a community that embraces otherness, and yet his own reading of the crucifixion sets up a stark rejection of otherness.

Perhaps the most divisive aspect of Rollins's theology of the cross, which is perhaps the reason for all of the above oppositions, relates to his ontology of violence (to borrow John Milbank's notion). Rollins sets up the self as fundamentally divided, but then insists that the only way that the self can be truly reconciled - that is, have its subjectivity transformed - is to participate in a 
further division, one in which Jesus is separated from the God who is the ground of meaning. Within a historical reading of the narratives of the Gospels, the cry of dereliction comes out of a particular set of circumstances. This indicates quite clearly that Jesus is murdered unjustly by an unjust political system. It is within and arguably because of this context that he experiences the trauma of abandonment. If, as in the rather absolutist terms of Rollins, trauma is required, then the system that produces the trauma is also required. Žižek (1992:64) seems aware of this in a way that Rollins has not yet articulated: "Sacrifice is a guarantee that "the Other exists": that there is an Other who can be appeased by means of the sacrifice'. To claim, as Rollins does, that we need to experience the crucifixion with Christ is to claim that the system that produces this violence is somehow good or necessary for our reconciliation with the God who transforms our subjectivities. To insist upon the crucifixion in this way, one can even go so far as to affirm the way that Judas betrayed Christ (Rollins 2008:21; Žižek 2003:16). Rollins, thus, becomes locked-in to the very sacrificial logic that he is trying to transcend (Rollins 2012:86-87). Contrary to this view, the Jesus of the Gospels does not seem to require the trauma even while he allows himself to undergo it. To say that something traumatic happens to the Christ on the Cross is not to say that it must happen, as René Girard demonstrates so well in his writings. As Rollins seems to intimate, the Cross certainly calls sociosymbolic systems of meaning into question, but in so doing it also calls the circumstances within which the cry of dereliction takes place into question. It may certainly challenge who we think God is, but it certainly presents an equal challenge to who we think we are and what kind of cruelty we are capable of inflicting even on the most innocent man.

To suppose the importance of the cross, not as challenging the logic of sacrifice but rather as a fundamental experience for understanding the structure of reality is to be in danger of reinforcing an opposition between a reasonable, metaphysical God and Rollins's God of subjectivity. And while there may be problems with a God who is totally constructed from the tools of human reason, there are surely also problems with a God who is so totally mysterious that he cannot even be vaguely understood via analogical language. However, it is unclear in Rollins's thinking why God must necessarily be completely separate from our human longings and desires, or why any Pascalian God-shaped-hole must automatically be an indication of original sin, which is automatically deemed to be a desire for the false God that is the big Other (Rollins 2012:19). By over-describing the perfect conditions within which doubt, complexity and unknowing are 'achieved', Rollins has set up a rigid system of prescriptions. ${ }^{6}$ The irony is obvious: we may keep our doubts only if we can be certain of how we got to them.

Of course, all this gives rise to the question regarding Rollins's hermeneutic strategy. He is clearly aware that 'as interpretive beings, we always filter the real world through our experiences, language, intelligence, culture and so forth' (Rollins 2006:11). What is most apparent and perhaps most problematic with regard to Rollins's hermeneutic of the cross is his thorough refusal of context, which is at its heart a refusal of the alterity of the text. I recognise that hermeneutic notions of context and continuity cannot necessarily be taken as a stable concerns. Nevertheless, a hermeneutics that utterly disregards these concerns risks setting itself up, not as a reconciliatory agent, but as a deeply divisive force. To say that context and continuity are unstable is not to say that they should be radically opposed. To be aware of their instability is simply to take heed of the limitations of the reader.

\footnotetext{
${ }^{6}$ Additionally, he points out the problems of prohibitions: they tend to act as invitations (Rollins 2012:28). And this, to me, seems to be the very same problem that we find in the prescriptivism of Rollins: by setting up a prohibition against reasonable and reasoned belief, he may have set up a repentance-free theological system where blind belief is made even easier; where one can believe that one can have faith beyond belief.
} 
I have argued from the start that Rollins follows Žižek too closely, as well as too uncritically, and my reasons for this stem from understanding Žižek's own hermeneutic approach. Žižek (2009:129-130) writes that '[p]erhaps the greatest test of the greatness of a work of work is its ability to survive being torn out of context'. Consequently, he prescribes the necessity of decontextualising the work - '[tearing] it out of the context in which it was original embedded'. With regard to his hermeneutic of the crucifixion, this is exactly what Rollins does. And while this yields interesting interpretive twists and turns, it does not necessarily yield a 'postdivisive' theology. Indeed, as I pointed out at the outset of this article, the trouble is that Rollins's theology of the cross stands in contravention of the very co-ordinates of his own project. To achieve a post-divisive theology, for instance, should not mean insisting upon greater divisions within the Trinitarian Godhead as being fundamental, but rather suggests the necessity of rethinking how we understand the paradoxical unity that remains even in difference. Love as that which connects - love, which is in the very nature of God - is only possible in division: in the relationships between persons, divine and human, and the created order.

A repeated concern throughout Rollins's writings is the concern that beliefs become too rigid to allow a genuine encounter with the reality. It is perhaps for this reason that he offers a pastoral affirmation of the place of doubt in the life of faith. He writes that to 'believe is human; to doubt, divine' (Rollins 2011a:19). It seems that his reading of the crucifixion certainly acts in support of this affirmation. Quite reasonably, doubt is understood not an anomaly in the life of faith but as a vital component of faith. Nevertheless, there is an inherent irony in setting up the importance of doubt in the way that Rollins has, especially through his hermeneutics of the crucifixion: doubt itself becomes the focus of certainty; that is, while faith is doubted, doubt is believed in. As I have noted above,
Rollins tries to set up a theology of the crucifixion around this axis of doubt, but in so doing he calls into question not only the context of scripture and not only divinity of Christ and the reality of God, but also his very own theological-political co-ordinates. To be able to set up a post-divisive theology, one first has to believe that such a thing is possible. To be able to transcend differences, one first has to acknowledge their presence. Whether Rollins's challenge to his own theology is intentional or not, it demonstrates, not that he has taken his doubting too far, but that he has simply not taken it far enough. Since it is Chesterton's own reading of the Cross that Rollins misinterprets, it seems only fitting to suggest Chesterton's own solution to this problem. He writes that "with the arrogant asserter of doubt, it is not the right method to tell him to stop doubting. It is rather the right method to tell him to go on doubting, to doubt a little more, to doubt every day newer and wilder things in the universe, until at last, by some strange enlightenment, he may begin to doubt himself" (Chesterton 2011:99).

\section{Bibliography}

Chesterton, Gilbert Keith. 1993. The everlasting man. San Francisco: Ignatius.

Chesterton, G.K. 2002. Orthodoxy: Annotated edition, edited by Craig M. Kibler. Lenoir: Reformation.

Chesterton, G.K. 2011. In defense of sanity: The best essays of GK Chesterton. San Francisco: Ignatius.

Corcoran, Kevin. 2011. Church in the present tense: A candid look at what's emerging. Grand Rapids: Brazos.

McKnight, Scot. 2007. Five streams of the emerging church. [O]. Available: http://www.christianitytoday.com/40534 Accessed: 13 March 2013.

Moody, Katherine Sarah. 2010. 'I hate your church; what I want is my kingdom': Emerging spiritualities in the UK emerging church milieu. The Expository Times 121(10): 495-503.

Moody, K.S. 2011. Retrospective Speculative Philosophy: Looking for Traces of Žižek's Communist Collective in Emerging Christian Praxis. Political Theology 13(2): 183-199. 
Pound, Marcus. 2008. Žižek: A (very) critical introduction. Grand Rapids: Eedmans.

Rollins, Peter. 2006. How (not) to speak of God. London: SPCK.

Rollins, P. 2008. The fidelity of betrayal. London: SPCK.

Rollins, P. 2011a. Insurrection. New York: Howard.

Rollins, P. 2011b. The worldly theology of emerging Christianity, in Church in the present tense: A candid look at what's emerging, edited by $\mathrm{K}$. Corcoran Grand Rapids: Brazos: 23-38.

Rollins, P. 2011c. Transformance art: Reconfiguring the social self, in Church in the present tense:
A candid look at what's emerging, edited by K. Corcoran Grand Rapids: Brazos: 89-104.

Rollins, P. 2012. The idolatry of God. London: Hodder \& Stoughton.

Žižek, Slavoj. 1992. Enjoy your symptom! New York: Routledge.

Žižek, S. 2001. Did somebody say totalitarianism? Five interventions in the (mis)use of a notion. London: Verso.

Žižek, S. 2003. The puppet and the dwarf: The perverse core of Christianity. London: Verso.

Žižek, S. 2005. The metastases of enjoyment: Six essays on women and causality. London: Verso.

Žižek, S. 2009. Violence. London: Profile. 